\title{
A Cooperative Script Learning Method Application Assisted By Interactive Multimedia To Improve Students' Cognitive Aspect Of 10th Grade At Vocational High School
}

\author{
Munir $^{1}$, Donni Triosa ${ }^{2}$ \\ \{munir@upi.edu ${ }^{1}$, donni.triosa94@student.upi.edu ${ }^{2}$ \} \\ Department of Computer Science Education, Universitas Pendidikan Indonesia, \\ Bandung, Indonesia ${ }^{1,2}$
}

\begin{abstract}
The background of this research is due to problems in learning computer systems at school. The purpose is to find out the improvement of students' cognitive aspects by applying a cooperative script method assisted by interactive multimedia on the subject of the computer system. The method used is an experimental method with a quasi-experimental form. The research design used is a nonequivalent control group design. Before conducting the research, the multimedia was validated first by the expert of material and the expert of multimedia. Based on the data processing, the result are 1) the improvement of the cognitive aspect in a control class has a gain index 0.37 , while in the experiment class is 0.78 . 2) The multimedia has a good response from the students and reached the percentage of $78.51 \%$.
\end{abstract}

Keywords: Cooperative Script, Cognitive Aspect, Interactive Multimedia

\section{Introduction}

Education is a well planned and conscious effort to create a learning atmosphere and process so that students actively develop their potential [1]. Education is also an effort from the community and the nation to develop a better and sustainable life for the young generation in the future. Such sustainability can be characterized by cultural heritage and character owned by people and nations [2].

Based on the implementation, education can occur within and outside school. Education within the school cannot be detached from teaching activities. Teaching activities generally occur through existing levels of education. The formal education levels are divided into basic, secondary and higher. The secondary education might be in the form of High School (SMA), Vocational High School (SMK), Madrasah Aliyah (MA), and Vocational Madrasah Aliyah (MAK) [1].

Based on the interviews conducted with one of the teachers at SMK N 1 Cisarua, the subject of Computer System is one of the difficult subjects for students of 10th grade, in the field of Software Engineering (RPL). The short number of study hours each week plus a large amount of material are the obstacles in the teaching and learning process in Computer System subject. The percentage of students who are able to exceed the minimum graduation criteria (KKM) in the Computer System is only 30\%. This is also consistent with the questionnaire 
results from students. Out of 25 students who filled out the questionnaire, $76 \%$ of them said that the material was difficult to understand.

In addition, $60 \%$ of the students said that the teaching and learning process on Computer System was not interesting. There are some materials which are considered difficult by student i.e. the material of Logic Relations and the functions of the Logic gate (52\%), the Arithmetic Logic Unit (ALU) (36\%), the material of number system (8\%) and Arithmetic Operation $(4 \%)$.

The low number of student who is able to surpass the KKM is the impact of difficulties faced by students. This shows the need for improvement in the teaching-learning process in the classroom not only to improve student learning outcomes but also achieve KKM. KKM is the minimum criterion that states the graduation of students in learning [3].

To improve student learning outcomes as well as to achieve KKM, the learning method become one important aspect. The learning method is a foundation derived from educational psychology and learning theory [4]. The selection of appropriate learning methods can be a solution so that students will not have difficulty in dealing with problems [5].

Learning models developed at this time are Cooperative Learning, Advance Organizer, Concept Attainmet, Inductive Learning, and Assist to Memory. Some methods developed recently in Cooperative Learning are Student Teams-Achievement Divisions, Jigsaw, Cooperative Integrated Reading and Composition, and Cooperative Script [6].

This research is used in a Cooperative Script method. Cooperative Script is a learning method where students work in groups and take the turn to verbally summarize parts of the material studied [7]. To create interesting learning for students, teaching aids are much needed. With the props, learning activities will be more interesting [5]. Thus, those teaching aids are used as learning media.

However, the number of teaching aids that can be used by teachers in learning is still minimum, especially for logic gate subjects. With the advance of information and communication technology, learning media can be converted into many interesting and fun forms called multimedia [8]. Multimedia is a computer usage for creating and combining text, graphics, audio, moving images (video and animation) to become tools that allow users to navigate, interact, create and communicate [9]. Multimedia comes from the words of multi and media. The word "media" comes from the word medium, which means an intermediary or introduction; "media" is the plural form of the medium to convey communication and information [10].

Based on the aforementioned description and background, the title of this research will be "A Cooperative Script Learning Method Application to Improve the Cognitive Aspects of SMK Students of 10th Grade Assisted by Interactive Multimedia".

\section{Methods}

\subsection{Research Methods and Design}

The research method used is experimental. The experimental research method consists of treatment that is given to the sample. The form used is the quasi-experimental form. The quasi-experimental is chosen because some things are impossible to control when conducting the research. 
This research used a nonequivalent control group design. There will be two classes, namely the experimental class and the control class which is estimated equal in the term of condition. They are not chosen randomly. The nonequivalent control group design is illustrated by the following Figure 1 below [11]:

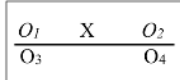

Fig. 1. Research Design.

Note:

$\mathrm{O}_{1} \quad=$ Pretest given to the experimental class

$\mathrm{O}_{2} \quad=$ Pretest given to the control class

$\mathrm{O}_{3} \quad=$ Posttest given to the experimental class

$\mathrm{O}_{4} \quad=$ Posttest given to the control class

$\mathrm{X}=$ Cooperative Script Learning Method assisted by interactive multimedia

\subsection{Research Procedure}

The procedure was carried out in 3 phases, namely planning, implementing and report writing. Each phase consists of several steps or activities.

Planning Phase. The phase carried out several steps to formulate the problem, research objectives, and determine the steps written in the research design. The Planning Phase consists of several stages, namely: 1) field study, 2) literature study, 3) problem formulation, 4) research design, 5) research instrument, 6) interactive multimedia development, and 7) validation by the expert.

Implementation Phase. This phase consists of field research with the experimental class and the control class. The student will be given a pretest to find out the student's initial abilities, before being given treatment. Next, students in the experimental class will be given treatment in the form of a cooperative script learning method application assisted by interactive multimedia. While students in the control class will be given treatment without using the cooperative script method. After that students will be given a posttest. The posttest is given to see the impact of treatment on student learning outcomes, by comparing the results of the pretest with the posttest.

Report Writing Phase. The last phase of the research is report writing. In general, the phase consists of two processes, namely:

Data Processing. The data of the pretest and posttest from the experimental class as well as control class are collected to be processed and analyzed. This data is processed by using descriptive analysis, normality test, homogeneity test, independent sample t-test, and gain test. In addition, data from the questionnaires were also processed to find out the shortcomings of interactive multimedia created.

Report Writing. The phase is carried out to document all research activities. The data processed and analyzed at this phase are also documented.

\subsection{Population and Sample}

The population in the research is students of 10th grade majoring in Software Engineering at SMK Cisarua I, West Regency of Bandung. The sample used in the experimental class is 
students of 10th grade of Software Engineering 1, as for the control class is the students of 10th grade of Software Engineering 2. Both are students at SMK Cisarua 1, West Regency of Bandung.

\section{Result and Discussion}

\subsection{Planning Phase}

An initial stage of this research is planning. The planning is a foundation before conducting research.

Field Study. The field study was conducted at SMK Cisarua 1, west regency of Bandung. It aims to gather information related to teaching and learning activity at school. Questionnaires are given to students. Besides, the researcher also conducted an unstructured interview with one of the teachers about which subject is considered difficult. The answers are concluded as follow: 1) one subject which considered difficult is Computer System, 2) students who are able to achieve the KKM at Computer System subject are only about 30\%. 3) the material of the number system, logic relation, logic gate function, and microcontroller are also difficult, 4) through the learning is using PowerPoint, the result is still passive. The interview result toward 25 students who filled out the questionnaire stated that $76 \%$ of students also considered Computer System subject is difficult.

In addition, $60 \%$ of students said that the teaching and learning process on Computer System subject was not interesting. Furthermore, there are some materials that are considered difficult by students. 52\% of students said that the material of Logic Relations and Logic gate functions are difficult. $36 \%$ of students stated that the Arithmetic Logic Unit (ALU) is a difficult subject. Yet, $8 \%$ of students considered Number System is difficult, while $4 \%$ of them stated that Arithmetic Operation is difficult. In the term of teaching, $76 \%$ of students stated that multimedia is not used in a computer system. While the other $24 \%$ stated that multimedia is indeed used. When the students were asked about their opinion of interactive multimedia usage, $32 \%$ of them considered it as interesting while the rest of $68 \%$ considered it as very interesting. None of them considered it as boring.

Literature Study (Theory). The researcher chooses the material of Logic Relation and Logic Gate Function based on the literature's study conducted to continue the previous research seen from the research result.

Research Instrument. An instrument is needed by the researcher to collect data. The instrument is used to measure the variable value of what being observed, as well as tools to collect preliminary data in the field study before conducting research. There are 4 types of instruments used, i.e. the instrument of field study, validation from the expert, student's cognitive aspect and student's response toward multimedia.

Multimedia Design and Development. Multimedia design in learning is needed. The design begins with the making of flowchart, storyboard, and interface. Next, the multimedia is developed by using Construct application. In the last phase, media testing is conducted by 
using 3 types of testing, namely: black-box testing by the developer, validation by multimedia expert and validation by a material expert.

\subsection{Implementation Phase}

The implementation phase is carried out after the multimedia is validated by an expert and declared to be suitable for use. The Cooperative Script method assisted by interactive multimedia is implemented at SMK Negeri 1 Cisarua, West Regency of Bandung. The samples are 26 students of $10^{\text {th }}$ grade of Software Engineering 1 as a control class and 25 students of $10^{\text {th }}$ grade of Software Engineering 2 as an experimental class. The implementation of the research took place on April 2 and 9, 2019.

First, students were given 20 questions of the pretest, before treatment being given. The pretest lasts for 30 minutes. It aims to find out the students' initial abilities. Next, a special treatment is being given to the students.

In the experimental class, the students are grouped into 2 and 3 people since the number is odd. Next, each student has to make a summary of logic relation material and logic gate functions from the multimedia made. After that, a member of each group has to read it out loud and the rest of the members should listen and make a correction. In the next step, the student switches their role. Then, the teacher will ask 2 students to present the result. And last, both teachers and students made a conclusion.

The control class is given a treatment also, yet the treatment is different from the experimental class. Students at the control class learn by using a book. They were asked to read the material in turn, while the other is writing.

After the learning is finished, students were given 20 questions of posttest to find out their ability after given the treatment. While at the experimental class, the students were asked to fill out a questionnaire about their responses toward the multimedia used.

\subsection{The Phase of Report Writing}

Data processing. The data of the pretest and posttest from both the experimental and control class were analyzed by conducting some testings.

Descriptive analysis. Based on the descriptive analysis result, there are 25 students of the experimental class and 26 students of the control class. The experimental class has an average score of 31.00 from the pretest and 84.80 from the posttest. While the control class has an average score of 35.00 from the pretest and 59.81 from the posttest.

Normality test. From the result of the normality test, it is found out that the sig. score for all data is $>0.05$, both from Kolmogorov-Smirnov and Saphiro-Wilk. Thus, it was concluded that the score of the pretest and posttest of both classes obtained from a normally distributed population (Table1).

Table 1. The result of normality test.

\begin{tabular}{|c|c|c|c|c|c|c|c|}
\hline \multirow[t]{2}{*}{ Class } & & \multicolumn{3}{|c|}{ Kolmogorov-smirnov } & \multicolumn{3}{|c|}{ Shapiro-wilk } \\
\hline & & Statistic & $\mathrm{df}$ & Sig. & statistic & df & Sig. \\
\hline \multirow[t]{2}{*}{ Control } & pretest & 0,154 & 26 & 0,116 & 0,937 & 26 & 0,114 \\
\hline & posttest & 0,145 & 26 & 0,168 & 0,947 & 26 & 0,193 \\
\hline \multirow[t]{2}{*}{ Experimental } & pretest & 0,169 & 25 & 0,064 & 0,934 & 25 & 0,110 \\
\hline & posttest & 0,152 & 25 & 0,138 & 0,940 & 25 & 0,149 \\
\hline
\end{tabular}


Homogeneity Test. From the result of the homogeneity test, the sig. score of the pretest is 0.671 , for both the control class and the experimental class. While the sig. score of the posttest is 0.204 .

Independent Sample t-test. The test is also called the average difference test. The sig. score of the independent sample t-test between the pretest of the control class and the experimental class is 0.107 . While the sig. score of the posttest is 0.000 .

Gain test. The gain analysis result of the control class showed that the index is in the middle category. The n-gain is 0.37 or $37 \%$. While the index in the experimental class is high. The n-gain is 0.78 or $78 \%$. Look at Figure 2 below.

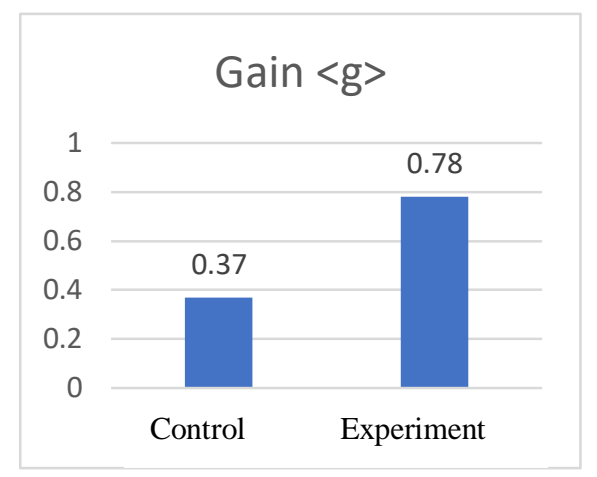

Fig. 2. The result of the gain analysis.

Based on the data analysis of student's responses toward multimedia, it is found out that the learning aspect has the highest percentage, i.e. $81.87 \%$. This percentage is categorized very well. The aspect of software engineering has a percentage of $79 \%$ and categorized well. Last but not least, the aspect of interface has a percentage of $74.08 \%$, and categorized well. In general, multimedia has a percentage of $78.51 \%$ and categorized well.

Report Writing. The report writing conducted to document all activities during the research. In addition, the data is analyzed, processed and also documented. The system of report writing in this research is in accordance with the university standards.

\subsection{Discussion}

Student's Cognitive Improvement. The research is conducted to Software Engineering 2 of 10th grade as the experimental class and Software Engineering 1 as the control class. Based on the data analysis result of the control class, the average score of the pretest is 35.00 with the lowest score is 20 and the highest one is 50. While the data analysis result of the posttest the average score obtained is 59.81, with the lowest score is 45 and the highest one is 75 . In the experimental class, the average score of the pretest is 31.00 with the lowest score is 20 and the highest one is 50. While the data analysis of the posttest in the experimental class has an average score of 84.80 with the lowest score is 70 and the highest one is 95 . To find out the quality improvement result of the student's learning in both control class and experimental class, an analysis of gain score then conducted. The result showed that the gain score in the control class is 0.37 . While in the experimental class, the gain score is 0.78 . Therefore, mathematically there is a difference of the gain score from both classes as much as 0.41 and 
judged from the gain improvement of the student's cognitive aspect, it showed that the experimental class has improved more compared to the control class.

Student's response toward interactive multimedia. In general, the student's response in the questionnaire showed a percentage of $78.51 \%$ and categorized well. It shows that multimedia learning has a positive response from students. As a user, they considered multimedia as a feasible feature to use. It also means that multimedia learning by using a cooperative method and material of Logic Relation and Logic Gate Function in the subject of Computer System has become a learning aid at SMK.

\section{Conclusion}

Based on the results of data processing, the gain score in the control class is 0.37 . While in the experimental class is 0.78 . Referring to the normalized gain category, the gain score of the control class is at the medium criteria, while in the experimental class is at the high criteria. This shows that the treatment by applying a cooperative script method assisted by interactive multimedia provides a significant increase in gain. In addition, based on the questionnaire results of student's responses, a percentage of $79 \%$ is obtained and categorized as good in the software aspect. This shows that multimedia can be used well during the learning process.

\section{References}

[1] R. Indonesia, Undang Undang No 20, Tentang Pendidikan Nasional, Jakarta.: Sekertariat Negara, 2013

[2] S. L. Rahayu, Fujiati a R. Dewi.: Educational Games as A learning media of Character Education by Using Multimedia Development Life Cycle (MDLC)," rev. The 6th International Conference on Cyber and IT Service Management (CITSM 2018), Medan, 2018

[3] A. Sudrajat.: penetapan-kkm.pdf,“ Agustus 2008. [Online]. Available: https://akhmadsudrajat.files.wordpress.com/2008/08/penetapan-kkm.pdf

[4] A. Suprijono.: Teori dan Aplikasi metode pembelajaran," Surabaya, 2009, p. 41.

[5] A. Sasongko.: Eksperimentasi Model Pembelajaran Koopertif Tipe CIRC (Coopertaive Integrated Reading and Composition) Dengan Alat Peraga Materi Peluang Pada Siswa Kelas XI SMK Wongsorejo Gombong Tahun 2011/2012,“p. 8, 2012

[6] M. Huda.: Cooperative Learning, Yogyakarta: Pustaka Pelajar, 2011

[7] R. Zamzani a Munoto.: Pengaruh Teknik Pembelajaran Cooperative Script Terhadap Hasil Belajar Siswa Pada Mata Diklat Menerpkan Dasar-Dasar Elektronika Pada Siswa Kelas X TAV di SMK Negeri 1 Sidoarjo,“ Jurnal Pendidikan Elektro, pp. 343-350, 2013

[8] D. R. Hidayanto, Munir, E. F. Rahman a J. Kusnendar.: The Application of ADDIE Model in Developing Adventure Game-based Multimedia Learning to Improve Students' Understanding of Basic Programming," 3rd International Conference on Science in Information Technology (ICSITech), pp. 307-312, 2017

[9] W. Pujiono, Y. Hendriana a I. D. Susanti.: Interactive Learning Media Based on RPP ICT,“ International Conference on Information Technology Systems and Innovation (ICITSI), 2016 
[10] Munir, H. Sutarno a N. S. Aisyah.: The development of interactive multimedia based on auditory, intellectually, repetition in repetition algorithm learning to increase learning outcome,“ Journal of Physics: Conference Series, pp. 1-9, 2018

[11] Sugiyono.: Metode Penelitian Pendidikan, Pendekatan Kuantitatif, kualitatif, dan R\&D, Bandung: Alfabeta, 2016 